\title{
THE MORAL IMPERATIVE TO \\ CONDUCT EMBRYONIC STEM CELL AND \\ CLONING RESEARCH
}

\author{
Katrien Devolder \\ Centre for Environmental Philosophy and Bioethics \\ Ghent University, Philosophy department \\ Blandijnberg 2, 9000 Ghent, Belgium
}

Tel: +32(0) 92644103

Email: katrien.devolder@UGent.be

\author{
Professor Julian Savulescu \\ Uehiro Chair in Practical Ethics \\ University of Oxford \\ Director, Oxford Uehiro Centre for Practical Ethics \\ Littlegate House, St Ebbe’s Street, \\ Oxford OX1 1PT, UK \\ Tel +44(0) 1865286888 \\ Fax +44(0) 1865286886
}

Email: julian.savulescu@st-cross.oxford.ac.uk

* Acknowledgments: Katrien Devolder acknowledges the stimulus and support of the European project "CLEMIT: developing an operational ethical framework to analyse and monitor the ethics of creating and 


\section{The United Nations Declaration on Human Cloning}

On 8 March 2005, the General Assembly adopted the United Nations Declaration on Human Cloning ${ }^{1}$ in which Member States are called upon to

(a) protect adequately human life in the application of life sciences

(b) prohibit all forms of human cloning inasmuch as they are incompatible with human dignity and the protection of human life;

(c) prohibit the application of genetic engineering techniques that may be contrary to human dignity

(d) prevent the exploitation of women in the application of life sciences

(e) adopt and implement national legislation to bring into effect paragraphs (a) to (d)

(f) take into account the pressing global issues such as HIV/AIDS, tuberculosis and malaria, which affect in particular the developing countries.

We will argue that cloning research does not exploit women (as d implies) and does address global health problems (not as $\mathrm{f}$ implies). More importantly, we will argue that it is immoral to prohibit all forms of cloning (as b suggests ) and that national legislation is required to ban reproductive cloning but not therapeutic cloning (and that e is too broad). This declaration fails to take account of new research into cloning and of the distinction between cloning research for the purposes of regenerative medicine (self-transplantation) and cloning research for the purposes of developing what we call cellular models of human disease. This second application is immune to virtually all objections to cloning research. $^{2}$ The United Nations should withdraw its unethical Declaration on Human Cloning. The Declaration is as immoral as it is lethal, or so we shall argue.

redesigning human beings", sponsored by the European Commission, DG-Research as part of the Science and Society research programme $-6^{\text {th }}$ Framework, in the preparation of this paper. The authors are also grateful to Norman Ford and Carolyn Cameron for their helpful comments on an earlier draft and to Konrad Hochedlinger for advice. 


\section{Breakthroughs in Cloning Research}

Two months after the adoption of the UN Declaration on Human Cloning, Woo Suk Hwang and colleagues of Seoul National University reported that they had successfully cloned 31 human embryos and had produced 11 embryonic stem (ES) cell lines from these. ${ }^{3}$ The cells were cloned from body cells from patients with diseases potentially amenable to stem cell therapy, including genetic disease, spinal cord injury and diabetes. This was the most important scientific event in cloning research since Ian Wilmut cloned a sheep, Dolly, in 1997. One year ago, the team in South Korea cloned embryos from a woman's body cells, using her own eggs. Twenty embryos were of good enough quality to extract stem cells. ${ }^{4}$

This new research is significant for several reasons. Firstly, it is indisputable evidence of cloning of human embryos. There were some concerns that the embryos in their 2004 research were parthenogenetic in origin. These embryos are clearly clones derived from donor oocytes and nuclear DNA from patient-donors. Secondly, the research is vastly more efficient. From, 185 eggs, 129 fused nuclear transfer constructs were created and 31 blastocysts survived. About 1 in 6 eggs produced a blastocyst. This is high in reproductive terms - only about 1 in 5 embryos become a baby. The process is 10 times more efficient than one year ago. The accelerating pace of progress in this area is illustrated in Table 1.

\section{Table 1. Milestones in Cloning and Embryonic Stem Cell Research}

1997 Wilmut et al, Nature, cloning of a sheep from a somatic cell

1998 Thomson et al, Science, derivation and culture of human embryonic stem cells

2004 Hwang et al, Science, first human embryo cloned and stem cell line developed from it- but from own egg

2005 Hwang et al, Science, first human embryo cloned from donor oocytes and from patients with disease or injury and successful derivation of self-compatible stem cell lines 
Thirdly, it opens up two radically new avenues for developing treatments for human disease and injury, which we will describe in more detail presently. Firstly, it is proof in principle of self-transplantation. Secondly, it opens the possibility of developing human cellular models of disease.

Cloning research is advancing quickly worldwide. In August 2004, the Human Fertilisation and Embryology Authority (HFEA) granted the first license for cloning human embryos in the UK. On May 19 2005, Alison Murdoch and her colleagues in Newcastle created the country's first cloned embryo from human somatic cells. ${ }^{5}$ Ian Wilmut also received a license to clone human embryos. The goal in all these research projects is not to use cloning as a form of assisted reproduction to create babies (what is sometimes called "reproductive cloning"), but to advance understanding of the causes and treatment of a whole range of currently incurable diseases and conditions, including neurological disease or injury and diabetes (sometimes called "therapeutic cloning" or as we prefer, "cloning for the purposes of research and therapy").

Many people, however, have expressed their disapproval of cloning research. Senator Sam Brownback, who takes a leading role in the anti-cloning movement in the U.S., said the research by scientists from Seoul National University "underscores the need for complete national and international bans on all human cloning," because "human cloning is wrong". ${ }^{6}$ Monsignor Elio Sgrecia, vice president of the Vatican's Pontifical Academy for Life, said, "you can't kill human life in the hopes of finding medicines to save other lives. This is not a victory for humanity but a crime twice over". ${ }^{7}$ Leon Kass, President of the U.S. President's Council on Bioethics, stated that "allowing cloned embryos to be produced for biomedical research and/or stem cell extraction is morally highly problematic. It crosses several important moral boundaries, accelerating our slide down a slippery slope (or, more accurately, jumping us off an ethical cliff) into a dehumanizing world of genetic control of offspring and the routine use of nascent human life as a mere natural resource". 8

\section{Embryonic stem cell research}


Before we discuss the concept of cloning for the purpose of research and therapy, it is necessary to review another recent scientific advance - the ability to culture human embryonic stem (ES) cells. Stem cells are undifferentiated or immature cells that have the capacity for unlimited or prolonged self-renewal, and, under the right conditions, for developing into one or several types of our body cells, such as liver cells or heart cells. These characteristics make them valuable means for research and therapy. Totipotent stem cells are cells with the potential to form a complete human being if placed in a uterus. They are early embryos. Pluripotent stem cells are undifferentiated stem cells with the potential to develop into any of the approximately 200 different mature cell types in the human body, but cannot by themselves form a complete human being if placed in a uterus. They can be obtained from the inner cell mass of the blastocyst or pre-implantation embryo. At this stage, the embryo is a microscopic ball of around 100200 cells, and is only a few days old and one tenth the size of a pinhead. Human ES cells were established for the first time in $1998^{9}$. Since then, the interest in ES cell research has increased significantly and, worldwide, researchers are investigating their potential and how to control their differentiation to specific types of body cells. Mouse ES cell lines have been induced to differentiate in vitro into a variety of cell types, including cardiomyocytes, hematopoietic progenitors, yolk sac, skeletal myocytes, smooth muscle cells, adipocytes, chondrocytes, endothelial cells, melanocytes, neurons, glia, pancreatic islet cells, and primitive endoderm. ${ }^{10}$ In January 2005, a Japanese team announced that it had successfully treated monkeys with Parkinson's disease through an ES cell transplant. ${ }^{11}$ ES cell technology has been described as the most significant development since recombinant DNA. ${ }^{12}$

\section{Cloning}

Cloning is the creation of a genetic copy of a sequence of DNA or of the entire genome of an entire organism. Although there are different cloning methods, in the cloning debate, the term "cloning" typically refers to somatic cell nuclear transfer (SCNT). This involves taking the nucleus with the DNA code of a somatic cell (any body cell other 
than a germ cell) and transferring it to an enucleated egg to create a totipotent stem cell or early embryo - capable of producing a clone or genetic copy of the entire genome from which it was derived. On February 24 1997, Scottish scientists announced that they had cloned Dolly the sheep using the SCNT technique. ${ }^{13}$ She was the first mammal ever to be cloned this way. Using SCNT to produce live offspring is often referred to as “reproductive” cloning.

The subject of this paper is cloning for non-reproductive purposes, that is, for research and therapy.

\section{The Human Significance of Cloning and Embryonic Stem Cell Research}

The recent research involving cloning of human embryos is of enormous significance for humanity. Indeed, California has devoted \$US 3 billion to this research. Dr. Hwang took mature cells from patients with genetic disease, spinal cord injury and diabetes, cloned them and produced 11 embryonic stem cell lines. These ES cells from patients with diseases have enormous significance for two reasons which are significantly different but currently conflated in debate about human cloning.

\section{Self-Transplantation}

The first reason why this research is important is because it is a leap towards selftransplantation. The objective of what is often indicated as "therapeutic cloning" is to produce pluripotent stem cells that carry the nuclear genome of the patient and then induce them to differentiate into replacement cells, such as cardiomyocytes to replace damaged heart tissue or insulin-producing beta-cells for patients with diabetes, ${ }^{14}$ or virtually any cell type, including sex cells. Dr. Hwang has shown that one day we may be able to take a skin cell from a patient with diabetes, clone it, derive ES cells, produce insulin producing cells from these and transfer the resulting cells back as a transplant. Because the cells would come from the patient, as in Hwang's experiment, there would be no need for drugs to prevent rejection, which can be lethal. Although cloning research is still in its infancy and much more research needs to be done, it may give us one day the possibility to produce "patient matched" tissue to repair damaged organs like the heart and brain, which have no capacity for regeneration, providing radical new 
treatments for stroke and heart attack, Parkinson's disease and many other diseases. This is regenerative medicine. It is the holy grail of medicine.

Rideout and colleagues recently reported the cure of a genetic disease using therapeutic cloning. ${ }^{15}$ They created a mouse with the Severe Combined Immunodeficiency (commonly known as the "boy in the bubble disease"). They took cells from the tail, subjected these to the cloning process, produced ES cells in which the gene was introduced to correct the genetic defect. These were introduced back into the mouse, curing the disease. This is the proof of principle for the therapeutic benefits of cloning.

Therapeutic cloning is important for several reasons:

1. There is a shortage of tissue for transplantation. As few as $5 \%$ of the organs needed ever becoming available, with the discrepancy between the number of potential recipients and donor organs increasing by approximately $10-15 \%$ each year in the US. $^{16}$

2. There are problems with compatibility of transplanted tissue requiring immunosuppressive therapy with serious side effects. Moreover, cloned tissue would be compatible without the infectious risks of xenotransplants.

3. The role of transplantation could be expanded to include common diseases like heart attack and stroke. After disease and injury, as occurs in stroke, the dead part of the brain is replaced by scar tissue, which serves only to maintain structural integrity. It is does not function as brain would function. It may be possible in the future to use therapeutic cloning to give stroke victims new brain tissue, with full or part functionality.

\section{Cellular Models of Human Disease}

The second reason why cloning research is important is because it opens up a whole new avenue of medical research. It could be used to study in a radically new way any disease in a culture dish. Cloning of a single skin cell could be used to produce inexhaustible amounts of cells and tissue from a patient with a certain disease. This tissue could be experimented upon to understand why disease occurs. It could be used to understand the 
genetic contribution to disease and to test vast arrays of new drugs. This would enable research that cannot be done in patients themselves or where there are too few patients to work with in case of rare genetic diseases ${ }^{17}$. At present, it is often impossible to safely take samples of affected cells from patients, especially those with genetic diseases that affect the brain or the heart. Ian Wilmut and his team want to create ES cell lines from embryos cloned from people with amyotropic lateral sclerosis (ALS), a currently incurable neurodegenerative condition. It is impossible to remove motor neurons from patients for study. Using cloning to create cultures of motor neurons from these patients would make it possible to investigate the cause of the disease and to test new therapies. Moreover, symptoms mostly develop after the disease has been progressing for some time, which makes the study of the cause of the disease more difficult. Cloning would facilitate this research by making it possible to monitor the progress of the disease as it develops inside the cells. ${ }^{18}$ It would also reduce the need for human and animal experimentation because human cells and tissues, not people or animals, could be used to test new drugs.

Other areas where this form of cloning would be very useful is the study of genetic variation and its interaction with environmental factors and the study of interactions between genes and drugs; the study of early human development and the underlying mechanisms regulating cell growth and differentiation, which would provide better knowledge and control over the manipulation and reprogramming of cells within patients; and the investigation of how pathogens interact with specific cell types, which would help to understand how to use viruses as a vehicle for reintroducing healthy genes to a damaged body ${ }^{19}$.

Most importantly, new treatments could be tested on the cells and tissues derived by cloning to test for safety and efficacy. Vast panels of potentially useful new chemotherapeutic agents could be tested, for example, on human cancer tissue without needing to extensive preliminary in animals or dangerous exposure of humans to highly experimental drugs. 
These two applications - self-transplantation and the development of cellular models of diseases - mean that cloning may be viewed as a scientific accomplishment on par with splitting the atom. But it will be vastly more beneficial to humanity. It may surpass the discovery of X-rays and penicillin.

\section{Acts and Omissions}

James Rachels was one of the first writers to argue that we are morally responsible and blameworthy not merely for the foreseeable and avoidable consequences of our actions, but also for the foreseeable consequences of our omissions, or what we fail to do, when we could have reasonably have acted otherwise. ${ }^{20}$ To fail to do beneficial research can as wrong as doing harmful research.

Imagine a scientific team, after 10 years of research, develops a cure to a disease which kills 100,000 people per year. Imagine that for one year, the team fights over who will have what fraction of the profits. As a consequence, the release of the drug is delayed by one year. Those scientists are as responsible for those deaths as if they had killed those 100,000 sick people. Now imagine an ethics committee delays release of the drug because of concern over the consent process - they are responsible for their deaths if their concerns are not well grounded and significant. Imagine now that instead the delay is not at the completion but at the very beginning - politicians prevent the research commencing for one year on some kind of moral grounds. Unless there are truly significant moral considerations, those politicians who cause the drug to be developed one year later than it could have been, are responsible for those 100,000 deaths. To fail to develop a drug which will save 100,000 lives is morally equivalent is morally equivalent to failing to release it. We may not be able to point to those people whose lives would have been saved but their lives are no less valuable because they are in the future or they are anonymous. Cloning research could result in treatments for common diseases like heart disease, stroke and cancer. It has a considerable potential to save hundreds of thousands if not millions of lives. Through a failure of moral imagination we may continue to hold back cloning research and be responsible for the deaths of many people who perished while we delayed the development of treatments. This research is of enormous potential benefit to humanity. This provides a strong prima facie case in favor 
not just of allowing cloning research, but positively supporting it through permissive legislation and generous public funding. The laws which prevent such life-saving research may be, in a moral sense, lethal.

There are, however, serious ethical objections. We will consider 5 of the strongest objections, showing this new research casts many of these in a new light.

\section{Objections to Cloning Research}

\section{Objection 1. Protection of human life}

The central objection to all ES cell and cloning research is that it represents the destruction of human life. At this time, it is not yet possible to extract ES cells without “killing” embryos.

The UN Declaration on Human Cloning calls upon Member States to "protect adequately human life" in the application of life sciences. The obvious question is what we understand under "human life” and “adequate protection”.

Some people believe that the human embryo is human life with the same moral value as a person. Therefore, embryos should never be used merely as a means, however beneficial the ends may be. “One may not heal by killing” said Cardinal Joachim Meisner with regard to ES cell research ${ }^{21}$. Others think embryos have the potential to become a person, and therefore should be protected as if they were persons.

It is not our intention to review the enormous volume of debate on the issue of the moral status of the embryo. What we do want to point out here is that cloning research allows us to understand the objection with regard to destroying human life in a different light. Many countries permit research on so called spare embryos, that is, embryos created during in vitro fertilization (IVF) which are no longer a part of a couple's reproductive plans. In his cloning research Dr. Hwang used eggs from young women who were not contemplating having children at that time (otherwise they would obviously not choose to take part in a research experiment that used their eggs). Dr. Hwang used "spare eggs" which would have otherwise perished. It is misleading to think that there are only two alternatives: either create certain embryos solely for the purpose of research or for the purpose of reproduction. This overlooks the fact that when the creation of embryos for 
research purposes becomes an issue, creation for reproduction is usually not a realistic alternative. $^{22}$ The alternative to research is to not reproduce at all. The young women taking part in Dr. Hwang's experiment were not trying to conceive at the time of the experiment and the eggs used would not have gone to produce a child if they had not taken part in the research. Instead of perishing for no reason, they were used to produce highly valuable stem cells. This research did not prevent any human beings coming into existence who would otherwise have come into existence.

Embryos may have a special moral status when they are a part of a parental project. That is why it would be wrong to destroy the embryos of a couple trying to have a child with IVF. But when a couple's family is complete or they do not want children, the value people accord to embryos often decreases. That is why society allows and in some cases requires the destruction of embryos when an infertile couple have completed their family using IVF, instead of requiring them to donate or adopt out those excess or spare embryos. And that is why the status of an embryo created for research is different to the status of an embryo created for the purposes of reproduction. Just as there are spare embryos not required for reproduction, so too there are "spare eggs" which are surplus to reproductive needs. Dr. Hwang's experiment used spare eggs and did not interfere with the reproductive intentions of any couple.

Women are born with millions of eggs and hundreds of thousands of eggs perish during their reproductive life as they will only have a limited number of, usually 1-3, children. Women have a right to control their reproduction and are not obliged to have as many children as they could possibly have. These eggs would never have produced a baby. Instead of perishing for no reason, they were used to produce highly valuable stem cells.

We have argued that there is a difference between the moral status of embryos created intentionally as a part of project to have a child ("wanted embryos") and those created unintentionally or for the purposes of research (“unwanted embryos”). Yet many people will continue to view embryos as children, and so not accept this distinction. But there is another way in which cloning research could be done without using human embryos at all. We could remove nucleus from a rabbit egg. DNA of a human skin cell introduced could be introduced in a nuclear transfer procedure (cloning). This chimera of a rabbit 
egg and human DNA would never develop into a living being - it stops development early in embryonic development at the stage when tissues are formed. However, human embryonic stem cells can be extracted from this construct and experimented upon to form cellular models of human disease. ${ }^{23}$ Since the entity produced would never continue development, no embryo would have been formed. This cloning research would not destroy a human embryo.

\section{Objection 2. Cloning is unnecessary}

Republican Senator Brownback, who introduced the Human Cloning Prohibition Act of 2003 (S. 245) in the U.S., stated that "human cloning is immoral and completely unnecessary. Recent advances in adult and non-embryonic stem cell research are showing that real results are being achieved without reliance on controversial human cloning technology”. ${ }^{24 .}$

This claim is false. Adult stem cells could not be used to produce cellular models of human disease as cloning and the production of embryonic stem cell lines could. This is a critical new line of research.

Adult stem cells have been found in several tissues of the human body, including skin, bone marrow, blood, the brain, and many others. Kogler and colleagues identified human adult stem cells from the umbilical cord blood with intrinsic pluripotent differentiation potential. ${ }^{25}$ There is a growing consensus among scientists on the great value of cord blood stem cells for transplantation. Over the last years there have been extensive discussions on which line of research is most promising. Those opposing ES cell research have often stated that ES cell research was not necessary since the same research goals can be reached with adult stem cells. ${ }^{26}$ However, work over the past 2 years has convincingly demonstrated that adult stem cells will not replace ES cells. Both cell types are different; they both have their advantages and disadvantages and will be useful for particular purposes. In some cases, combined ES cell and adult stem cell therapy might be the best option. ${ }^{27}$ Therefore, further research is required on both cell types. 
Those who are against the creation of embryos solely for their stem cells argue that we could make optimal use of existing spare IVF embryos. However, there is a limited availability of good quality spare embryos. Moreover, researchers do not have control over the genetic make-up of the cells in these embryos, which presents rejection problems if they don't genetically match the patient in need of a transplant. ${ }^{28}$ They wouldn't have the same advantages as cloned cells for studying the causes of genetic diseases and pharmaceuticals. Scientists need to create new cells that actually have genetic diseases in order to study how these diseases affect the growth and development of other cells and tissue. Moreover, stem cells from spare embryos would not be sufficiently racially or ethnically diverse. If research purposes can be reached by using spare IVF embryos, then we should first make use of these. It is surely better to use the existing embryos for beneficial purposes than to discard them. But cloning is necessary if we are properly to extract the full potential to develop cellular models of human disease.

\section{Objection 3. Slippery Slope to Reproductive Cloning}

Another objection to cloning research is that this brings us "one step closer" to human reproductive cloning - cloning to produce babies. In his statement "Farming humans for fun” Richard Doerflinger, of the U.S. Conference of Catholic Bishops, said that "human cloning's slippery slope toward complete dehumanization of human beings will not stop until the U.S. Senate passes Senator Brownback's complete ban on human cloning”. 29 Leon Kass, President of the President's Council on Bioethics, called for federal legislation to stop human cloning for any purpose. He stated that "the age of human cloning has apparently arrived: today, cloned blastocysts for research, tomorrow cloned blastocysts for babymaking". ${ }^{30}$

Reproductive cloning is unlikely to ever be safe. This is based on observation of cloned animals (mostly mice and cows) that have hundreds of genes that are abnormally expressed, in particular genes important for fetal development (so called imprinted genes). This results in abnormalities during development (95\% or more of cloned embryos abort), at birth ("large offspring syndrome") or later in life (even seemingly normal mice often develop obesity, die prematurely, develop tumors compared with

controls). It has been said that there are "biological barriers" to reproductive cloning. ${ }^{31}$ 
Interestingly, cloning to produce stem cells should be safe because the genes that cause the cloned embryos to be abnormal are not important for the derivation of ES cells (there is no fetal development). In addition, the isolation of ES cells is a selection process where "normal" cells will grow out into an ES cell line whereas "abnormal" (not fully reprogrammed cells) will be selected against.

The response to fears about reproductive cloning is not to ban cloning altogether. It is to ban reproductive cloning.

According to Carol Tauer, of the Center for Bioethics at the University of Minnesota, the reason why the UN and the US Congress failed to pass a worldwide ban on reproductive cloning is that there is a strong link between reproductive and therapeutic cloning. ${ }^{32}$ Most countries want to postpone a decision on whether to allow cloning research or not.

To ban cloning research because of fears about reproductive cloning is not just to throw the baby out with the bath water. It is possibly to throw millions of babies out.

It is possible to separate legislation of research from legislation of its application. The UK provides one example of a country which has successfully allowed cloning for research and therapy but has banned cloning of people. The UK's Human Reproductive Cloning Act 2001 section 1(1) says:

A person who places in a woman a human embryo which has been created otherwise than by fertilisation is guilty of an offence. The act makes it illegal to gestate a cloned embryo ${ }^{33}$.

The slippery slope argument is, in many cases a specious one, which is intended to conceal the lack of serious reasoning. The image of a slippery slope is misleading. If a metaphor must be used then we should speak of a staircase upon which we could descend, step by step, until we have reached a certain level. Some levels are desirable, others are not. There is no reason why we should no be able to remain on a certain level and consider calmly whether or not we want to take the next step. We could even turn the slippery slope argument on itself: if we accept appeal to the slippery slope argument, 
then we quickly slide down to a level at which any rational discussion becomes impossible.

Either legislation is ineffective or it is effective. If it is ineffective, laws banning cloning will be ineffective, so we may as well reap the rewards of research into therapeutic cloning. If they are effective, we should ban only reproductive cloning and allow therapeutic cloning with all its potential benefits.

\section{Objection 4. Economic and Social Justice Considerations}

Stem cell and cloning research have huge economic potential - California has injected \$US 3 billion into this research. However, there remain important economic and social justice objections to this research. The research is sometimes said to be a Western luxury, which will be unaffordable to most of the world. It is unjust to devote limited resources to such research.

Indeed, the UN appears seduced by this worry. Its Declaration on Human Cloning, in its final point, calls upon Member States, "in their financing of medical research, including life sciences, to take into account the pressing global issues such as HIV/AIDS, tuberculosis and malaria, which affect in particular the developing countries”.

The objection from justice is more acute in light of the following three alleged problems with cloning research.

\section{Unsafe}

There are numerous unanswered questions as to the control of ES cell growth and differentiation. ES cells have the potential to be tumorigenic, growing into teratomas and teratocarcinomas when injected into mice. Research is being done on this worldwide and progress is being made. ${ }^{34}$

Recent research shows there may be infectious and other risks, such as occurred with BSE, of transplanting such tissue back to people, when it is grown on foreign culture material. $^{35}$

\section{Labor intensive and expensive}


Anne McLaren, the famous British geneticist, remarked that therapeutic cloning would probably be a realistic option only for the very rich and that "any such personalized treatment will always remain labor intensive, and hence, expensive". 36 "Clone-ialism” is the pejorative term that extends this idea: medically advanced countries will try to exploit less advanced ones and biotechnology will facilitate this trend. ${ }^{37} 38$

But current treatments and care for patients suffering from chronic diseases for which ES cell therapies may be used, are also expensive and labor intensive. Moreover, therapeutic cloning may cure these diseases and not only treat them. Therapies are also likely to become cheaper, easier and accessible to more people after some time.

The whole cloning procedure takes a long time and some clinical applications may not allow for this (e.g. myocardial infarction, acute liver failure or traumatic or infectious spinal cord damage). Therapeutic cloning would likely be reserved for chronic conditions.

Apart from this, as Ian Wilmut has pointed out, "not all diseases are equal in terms of expense, and treatments could be targeted to maximize benefit. An older person with heart disease, for example, could be treated with stem cells that are not a genetic match, take drugs to suppress their immune system for the rest of their life, and live with the side-effects. A younger person might benefit from stem cells that match exactly”. ${ }^{39}$

\section{The exploitation of women}

If cloning with embryos were permitted, it would require, to be effective, a large number of eggs or oocytes. In a speech of the Holy See to the UN, Archbishop Migliore stated that, "the process of obtaining these eggs, which is not without risk, would use women's bodies as mere reservoirs of oocytes, instrumentalizing women and undermining their dignity". 40

The UN Declaration on Human Cloning also stresses this point and calls upon Member States to take measures to prevent the exploitation of women in the application of life sciences.

However, the problem of the need for large numbers of eggs from women is likely to be a short term problem for several reasons. First, one of the main purposes of cloning is to 
perform research to understand how cells develop and can be reprogrammed to an immature state. Once that is understood, the process can be replicated in a laboratory and there will be no need for new eggs. Second, researchers are investigating the use of alternatives, including fetal oocytes and eggs from adult ovaries, obtained post mortem or during operation. ${ }^{41}$ In June 2005, a team of Belgian scientists reported at the annual conference of the European Society of Human Reproduction and Embryology (ESHRE) that they had cloned human embryos using human eggs matured in the laboratory. They hope one day this will make it possible to perform therapeutic cloning by creating artificial eggs from patients' body cells. Another alternative is the differentiation of ES cells in culture into germ cells and full-grown oocytes. ${ }^{42}{ }^{43}$ Scientists from the University of Sheffield stated at the ESHRE conference that human ES cells can develop into primordial germ cells - the cells that eventually become eggs or sperm. Recent studies have found that mammals may continue to produce new eggs throughout their live. If 'ovary stem cells' really exist, this could make it possible to produce more eggs $^{44}$. Another option researchers are investigating is the use of non-human oocytes such as frog eggs, for the purpose of cloning research. ${ }^{45}$ Another possibility is to ask people undergoing IVF to donate one or two of their eggs. These women undergo the risk of hormone stimulation anyhow. The research team at the University of Newcastle upon Tyne has received permission to ask IVF patients to give up two eggs from each batch collected for their treatment.

Of course, if self-transplantation is perfected, families, eager to help their dying or sick relative, may well volunteer sufficient eggs for the treatment of their sick relative.

\section{Is Cloning Research Unjust?}

These three considerations have led some to suggest that it is unjust and wrong to do cloning research. As we have alluded, each of these specific objections may have solutions in future. But most importantly, none of these considerations applies to the second application of cloning research: to provide cellular models for human disease. This will enable research into and the development of drugs to treat common diseases, like cancer and heart disease, which afflict people all over the world. These drugs may 
be inexpensive. Concerns about infection and safety do not apply to this research as it is about understanding disease and developing drugs in laboratory where there would be no chance of infection. It is not labor intensive - it is experimenting on cells and tissues which is done now in animals. It would not require large numbers of eggs as a few eggs would produce inexhaustible amounts of tissue to study a particular disease, since embryonic stem cells produce immortal cell lines. In so far as these objections have force, they only have force against cloning for self-transplantation, not cloning for developing cellular models of human disease.

\section{Objection 5. Disruption of the Moral Fabric of Society}

There are concerns that this research is moving too fast and the community is not ready to accept it. People in society hold different values and these differing values must be respected. Concerns that moral fabric and cohesiveness of society will be torn apart provide reasons for care and reflection. But precaution must be balanced against delay in developing life-saving treatments. We must remember that many innocent children and adults are at stake. We believe that an understanding of the differences between reproductive cloning and cloning for the purposes of research and therapy, if properly understood, would allay the concerns of many citizens. Moreover, understanding the concept of cloning to produce models of human disease, to test new treatments, should convince some of the legitimate scientific merits of this research. Further strategies to promote community acceptance and cohesiveness include:

1. Transparency. High quality, clear information about the research and its limitations. The public must understand the science.

2. Public Control and Predictability. People fear that scientists are opening Pandora's box. There must be some predictability and sense of control over the research.

3. Legislative Control. Related to 2, bans on reproductive cloning are required to achieve control over the application of this research.

4. Independent Oversight. Apart from legislation, the public may require independent oversight of scientists, through ethics committees of licensing bodies such as the HFEA and the Embryonic Stem Cell Research Oversight (ESCRO) committee 
proposed by the National Academy of Sciences in their report "Guidelines for Human Embryonic Stem Cell Research”. 46

5. Review. The field is rapidly evolving and there is a need to frequently review the adequacy of controls.

6. Participation and respect for value diversity. Individuals and cultures have different values. It is important that those different values be respected through giving individuals and particular cultures a voice, and formulating the research in light of those concerns.

7. Reassurance and Demonstration of Benefit. People need reassurance that the risks are being managed and that benefits are occurring. Most importantly, the public needs to see that these benefits are returning to citizens.

\section{Conclusion}

There are good reasons to pursue cloning research. There is potential to immeasurably increase scientific understanding of cellular development and control. There is the potential to revolutionize the practice of transplantation medicine which may significantly prolong human life. Understanding the two different applications of cloning - self transplantation and the development of cellular models of disease - helps us to address many of the objections. Cloning to produce cellular models of disease would require relatively few eggs to produce vast amounts of tissue for the study of disease. This may result in the development of drugs for common conditions which afflict people all around the world, including in the developing world. And finally, there would be no risk of infection from drugs developed by studying tissue in this way as the drug molecules would be produced pharmaceutically. Cloning research can be pursued using spare eggs which would not interfere with reproduction. Using animal eggs, oocytes grown in the laboratory, or stem cell derived eggs would avoid the problem of egg shortage entirely.

The critical point is that we cannot predict in advance the results of scientific research. What this research turns up may be very different to what is promised. But it may be 
very important nonetheless. There is an important distinction between the regulation of research and the formation of social policy and law. Research should only be prevented if it harms people or exposes them to unreasonable risks. This research does not harm any person. It only stands to benefit people. We must do the research, then form the policy on the basis of the results, not in advance of them, not in prediction of them and not in fear of them. Scientific research is like trying to pick the winner of a horse race. There can be favorites, but one can never know in advance which horse will win. The race has to be run.

Just as we were able to co-ordinate nations all over the world through the Human Genome Project, we need a Cloning and Stem Cell project, where all governments facilitate this research and scientists co-ordinate, sharing knowledge and stem cell lines, to bring treatments to people quicker. We need global co-ordination of research which involves universal bans on reproductive somatic cell cloning, and scientific co-ordination that facilitates research. When it comes to research into lethal diseases, time is not only money, it is human lives. Sometimes many human lives.

The United Nations must immediately retract its misguided and immoral Declaration on Human Cloning before it consigns many more future people to early and avoidable suffering and death. Twenty-one nations in Europe prohibit cloning research. ${ }^{47}$ Declarations, laws and policies that prevent or retard this research may prove in the future to have been a death sentence to our children. All countries must work towards a universal ban on human reproductive cloning. But equally, they must all work together to facilitate and encourage cloning for the purposes of research and therapy.

1 United Nations General Assembly. Resolution Adopted by the General Assembly: United Nations Declaration on Human Cloning. Fifty-ninth session, Distr.: General 23 March 2005.

2 Savulescu J. Cloning benefits akin to discovery of X-rays. The Australian, June 4, 2005, 19. (Several of the arguments in this paper first appeared in brief form in this newspaper opinion piece.)

3 Hwang WS, Roh SI, Lee BC, Kang SK, Kwon DK, Kim S, et al. Patient-specific embryonic stem cells derived from human SCNT blastocysts. Science 2005;308:1777-83.

4Hwang WS, Ryu YJ, Park JH, Park ES, Lee EG, Koo JM et al. Evidence of a pluripotent human embryonic stem cell line derived from a cloned blastocyst. Science 2004;303:1669-74. 
5 Stojkovic M, Stojkovic P, Leary C, Hall VJ, Armstrong L, Herbert M et al. Derivation of a human blastocyst after heterologous nuclear transfer to donated oocytes. Reproductive BioMedicine Online 2005;11.

6 Price JH. Brownback pushes his anti-cloning bill. The Washington Times, Feb 16, 2004.

7 Anonymous. Vatican slams human embryo cloning. CNN.Com International; 13 Feb 2003. At:

http://edition.cnn.com/2004/WORLD/europe/02/13/vatican.clones.reut/.

8 Kass LR. Drawing the line between ethical regenerative medicine research and immoral human

reproductive cloning. Testimony for the United States Senate Committee on the Judiciary; 19 March 2003.

9 Thomson, JA, Itskovitz-Eldor, J, Shapiro, SS, Waknitz, MA, Swiergiel, JJ, Marshall, VS, Jones, JM.

Embryonic stem cell lines derived from human blastocysts. Science 1998; 282:1145-7.

10 Odorico JS, Kaufman DS, Thomson JA. Multilineage differentiation from human embryonic stem cell lines.Stem Cells 2001;19:193-204.

11 Takagi Y, Takahashi J, Saiki H, Morizane A, Hayashi T, Kishi Y et al. Dopaminergic neurons generated from monkey embryonic stem cells function in a Parkinson primate model. Journal of Clinical Investigation 2005;115:102-9.

12 Campbell KH, McWhir J, Ritchie WA, Wilmut I. Sheep cloned by nuclear transfer from a cultured cell line. Nature 1994; 380:64-6.

13 Wilmut I, Schnieke AE, McWhir J, Kind AJ, Campbell KH. Viable offspring derived from fetal and adult mammalian cells. Nature 1997; 385:810-3.

14 Lanza RP, Cibelli JB, West MD. Prospects for the use of nuclear transfer in human transplantation. Nature Biotechnology 1999; 17:1171-4.

15 Rideout WM, Hochedlinger K, Kyba M, Daley GQ, Jaenisch R. Correction of a genetic defect by nuclear transplantation and combined cell and gene therapy. Cell 2002;109:17-27.

16 Cooper DKC. Xenotransplantation - state of the art. Frontiers of Bioscience 1996; 1: 248-65.

17 Lovell-Badge R. The future for stem cell research. Nature 2001;414:88-91.

18 See note 12, Wilmut, Schnieke, McWhir, Kind, Campbell 1997.

19 Solter D,Beyleveld D, Friele MB, Holwka J, Lilie H, Lovell-Badge R et al. Embryo Research in

Pluralistic Europe. Berlin Heidelberg: Springer-Verlag, 2003:105.

20 Rachels, J. The End of Life, Oxford: Oxford University Press, 1986

21 Anonymous. Key German stem cell vote awaited. CNN.com; 30 Jan 2002. At:

http://edition.cnn.com/2002/WORLD/europe/01/30/germany.europe1040/.

22 Persson I, Savulescu J. Reproduction and Embryo Research: Bringing Embryos into Existence for Different Purposes, or Not at All in Holm S, Festschrift for John Harris, forthcoming.

23 Mandavilli A Scientists seek simple remedies to cloning conundrums. Nature Medicine 2005;11:459.

24 Anonymous. Brownback, Weldon \& member of European Parliament discuss ban on human cloning. 25 June 2003. At: http://brownback.senate.gov/record.cfm?id=205465.

25 Kogler G, Sensken S, Airey JA, Trapp T, Muschen M, Feldhahn N et al. A new human somatic stem cell from placental cord blood with intrinsic pluripotent differentiation potential. The Journal of Experimental Medicine 2004;200:123-35.

26 Center for Bioethics and Human Dignity. On Human Embryos and Stem Cell Research: An Appeal for Ethically Responsible Science And Public Policy; 1 July 1999. At:

http://www.cbhd.org/resources/stemcells/position_statement.htm.

27 Camargo FD, Chambers SM, Goodell MA. Stem cell plasticity : from transdifferentiation to

macrophage fusion. Cell Proliferation 2004; 37:55-65.

28 See note 12, Wilmut, Schnieke, McWhir, Kind, Campbell 1997.

29 Doerflinger RM. Farming Humans for Fun and Profit. Life Issues Forum; 20 Jan 2004. At:

http://www.usccb.org/prolife/publicat/lifeissues/012004.htm.

30 Kolata G, Grady D. Human embryos cloned in S. Korea. Star-Telegram; 12 Feb 2004. At:

http://www.dfw.com/mld/dfw/7936289.htm?1c.

31 Hochedlinger K. Nuclear Transfer to create stem cells. Paper presented at the annual symposium of the Australian Academy of Sciences: Recent Advances in Stem Cell Science and Therapies. 6 May 2005,

Canberra.

32 Tauer, C A. International policy failures: cloning and stem-cell research. The Lancet 2004; 364:209-14.

33 UK Human Reproductive Cloning Act 2001. 
At: http://www.uk-legislation.hmso.goc.uk/acts/acts2001/20010023.htm.

34 Sylvester KG, Longaker MT. Stem cells: review and update. Archives of Surgery 2004; 139:93-9.

35 Braude P, Minger SL, Warwick RM. Stem cell therapy: hope or hype? BMJ, May 2005; 330: 1159 - 1160.

36 McLaren A. Ethical and social considerations of stem cell research. Nature 2001; 414:129-31.

37 Rifkin J. The Biotech Century: Harnessing the Gene and Remaking the World. NY: Tarcher; 1999.

38 Buchanan A, Brock D, Daniels N, Wikler D. From Chance to Choice. NY: Cambridge University Press; 2000.

39 See note 12,Wilmut, Schnieke, McWhir, Kind, Campbell 1997.

40 Holy See Mission. Holy See's call for a ban on all human cloning: UN Speech by Archbishop Migliore, 30 Sept 2003. At : http://www.catholic.org/featured/headline.php?ID=385.

41 Klinger FG, De Felici M. In vitro development of growing oocytes from fetal mouse oocytes: stagespecific regulation by stem cell factor and granulose cells. Develomental Biology 2002; 244:85-95.

42 Hubner K, Fuhrmann G, Christenson LK, Kehler J, Reinbold R, De La Fuente R et al. Derivation of oocytes from mouse embryonic stem cells. Science 2003; 300:1251-6.

43 Testa, G, Harris, J. Ethical aspects of ES cell-derived gametes. Science 2004; 305:1719.

44 Anonymous. Women produce new eggs, study suggests. BioNews; 15 March, 2004.

45 Byrne, J.A, Simonsson, S, Western, PS, Gurdon, JB. Nuclei of adult mammalian somatic cells are directly reprogrammed to oct-4 stem cells gene expression by amphibian oocytes. Current Biology 2003;13: 1206 - 13.

46 Committee on Guidelines for Human Embryonic Stem Cell Research, National Research Council. Guidelines for Human Embryonic Stem Cell Research. Washington D.C.: The National Academies Press; 2005.

47 Center for Genetics and Society. National Policies Governing New Technologies of Human Genetic Modification. A Preliminary Survey. At: http://www.genetics-and-society.org/policies/survey.html (accessed February 2004). 